\title{
Heid Leganger-Krogstad En vidtfavnende religionsdidaktisk forskningsinnsats
}

\author{
Av Elisabet Haakedal, \\ professor i religionspedagogikkved Universitetet i Agder. Epost: elisabet.haakedal@uia.no
}

I 1984 leverte Heid Leganger-Krogstad hovedfagsoppgaven «Jesu liknelser $i$ grunnskolens undervisning. Liknelsene som kommunikasjonsmidler analysert under didaktisk synsvinkel». Den er fortsatt relevant i religionsdidaktisk sammenheng på grunn av dens nybrottsarbeid med narratologi i bibelvitenskapene. I mai 2018 holdt professor Leganger-Krogstad sin avskjedsforelesning med tittel «Bibelundervisning i kirken - utfordringer og muligheter». Etter den tid har hun skrevet to forskningsrapporter om bibelundervisning i trosopplæringen. Dermed var ringen sluttet på bibeldidaktikkens område. Hennes religionsdidaktiske $^{1}$ innsats spenner likevel langt videre.

Typisk for Leganger-Krogstad er hennes kombinasjon av forskning og praksisrettet undervisning. Etter flere år som grunnskolelærer ble hun fra 1980 tilsatt ved Høgskolen i Alta. Her finnes sentrale røtter til Leganger-Krogstads engasjement for kontekstuell religionsdidaktikk idet hun tok inn over seg gapet mellom læreb $\emptyset$ ker som formidlet fagstoff preget av det sentrale $\emptyset$ stlandsområdet, og skolevirkeligheten slik den fortonte seg i små bygdesamfunn i Finnmark. En hovedtanke hun utviklet i disse årene, gjaldt hvordan lærere med fordel kan samarbeide med lokalsamfunnets tros- og livssynsorganisasjoner slik at elevene får et møte med «levd» tro og praksis i tillegg til lærebøkenes representasjoner. Slik ble en lærebok i kontekstuell religionsdidaktikk til i samarbeid med Geir Afdal og undertegnede.

Fra 1996 fikk Leganger-Krogstad stilling i religionsdidaktikk ved Institutt for lærerutdanning og skoleforskning (ILS) ved Universitetet i Oslo. Hun bidro til utdanningen av store kull religionslærere, og gjennom utallige skolebes $\emptyset \mathrm{k}$ fikk hun nærkontakt med Oslo-skolen. Her utforsket hun kontekstuell religionsdidaktikk videre. I Towards Religious Competence. Diversity as a Challenge for Education in Europe (2001) finnes Leganger-Krogstads kanskje mest sentrale forskningsbidrag. I det tar hun utgangspunkt i sitt Alta-baserte empiriske case-studium (med lokalt etnisk og intrakristent mangfold, bl.a. kvenskættede læstadianere) og underbyg-

1 I denne presentasjonen er en innholdsmessig tilnærmet overlappende bruk av betegnelsene «religionsdidaktikk» og «religionspedagogikk» bevisst valgt. 
ger teoretisk og argumentativt en generalisering av kontekstuell religionsdidaktikk med referanse til global-lokale flerkulturelle og flerreligiøse skolesamfunn, slike som for eksempel lærerutdanningen ved ILS betjente.

Leganger-Krogstads doktoravhandling dokumenterer hennes kontekstuelle religionsdidaktikk som et samlet forskningsprosjekt (The Religious Dimension of Intercultural Education. Contributions to a Contextual Understanding, 2011). I en senere publikasjon sammenligner hun ulike typer av mangfoldsbaserte religionsdidaktiske tilnærminger slik at hun får understreket særpreget på den typen hun selv går inn for. ${ }^{2}$ I sin kontekstforståelse framhever hun et skolefagsinnhold som både er tradisjonsforankret og lokalsamfunnsforankret.

Leganger-Krogstad har bidratt betydelig både nasjonalt og internasjonalt til å styrke religionspedagogisk forskning, bl.a. gjennom styreverv i Norsk religionspedagogisk forskerforum (NoReFo), oppbygging av The European Network for Religious Education through Contextual Approaches (ENRECA), og hyppige tekstframlegg på International Seminar on Religious Education and Values (ISREV). Hun har også bidratt med sin fagkompetanse i oppdrag under skolereformen Kunnskapsløftet og gjennom frivillig engasjement i den pågående 2020-fagfornyelsen.

Etter tusenårsskiftet sto Leganger-Krogstad ved et veivalg. Skulle hun fortsette ved ILS eller finne tilbake til en «tidlig kjærlighet», nemlig kirkelig religionsdidaktikk? Hun valgte det siste og ble tilsatt på fagfeltet religionspedagogikk ved MF. Her har hun bygd opp og ledet fakultetets masterprogram i kirkelig undervisning - kateketutdanningen - og veiledet 40 masteravhandlinger innen feltet. I alle år har hun samtidig vært lærer i menighetspedagogikk på avsluttende praktikum for å bidra til at ferske prester kjenner arbeidsfeltet trosopplæring og kan medvirke til dette.

I sin stilling på MF har Leganger-Krogstad kunnet trekke veksler på sine gode forbindelser med det tyske religionspedagogiske forskningsmiljøet. ${ }^{3}$ Tyske kolleger innenfor praktisk teologi jobber både skole- og kirkerettet pga. deres konfesjonsbaserte religionsundervisning og forsker både på formell og ikke-formell religionsundervisning. Leganger-Krogstad har samarbeidet med kolleger innen protestantisk kirkelig og skolebasert religionspedagogikk blant annet gjennom Intereuropean Commission on Church and School (ICCS), og hun har deltatt i en ekspertgruppe i Europarådet om religionsdimensjonen ved interkulturelt arbeid.

2 Leganger-Krogstad, H. (2013). An Analysis of Different Approaches to Religious Education. I: Skeie, G., Everington, J., ter Avest, I., Miedema, S. (red.): Exploring Context in Religious Education Research. Empirical, Methodological and Theoretical Perspectives (pp. 171-191). Münster: Waxmann

3 Se for eksempel Leganger-Krogstad, H. (2009). Evaluationsforschung zur Glaubenserziehungsreform in Norwegen. I: Schweitzer, F., Elsenbast, V. (Hg.): Konfirmandenarbeit erforschen. Ziele - Erfahrungen - Perspektiven (s. 140-157). Gütersloh: Gütersloher Verlagshaus. 
Leganger-Krogstad var sentral i flere forskergrupper som har hatt Den norske kirkes trosopplæring som sitt primære forskningsobjekt: ETOR (Evaluering av trosopplæringen), LETRA (Lærings- og kunnskapsbaner i Den norske kirke), FoSS (Forkynnelse for små og store), Trosopplæring som drivhjul i menighetsutvikling? og BIT (Bibelen i trosopplæringen). Hun har også bidratt i tyske nettverk. ${ }^{4}$

Enda et spennende prosjekt hvor Leganger-Krogstad har vært en inspirator og fagkonsulent, er Tidslinjen - Den store fortellingen i Bibelen hvor den sentrale artefakten er en illustrert tidslinje fra skapelse til nyskapelse. Til hver av de mer enn 60 enkeltfortellingene som er illustrert, hører gjenfortalt tekst og forslag til undervisningsopplegg tilpasset tre aldersgrupper. Tidslinjen finnes i digitalt format på åpent nettsted (http://tidslinjen.bibel.no/normal/1) og som plastruller. Det pedagogiske opplegget finnes digitalt og i bøker. LegangerKrogstad har skrevet innledningen til lærerveiledningen. Leganger-Krogstad har dessuten deltatt i revisjon av Konfirmantbibelen og har skrevet den generelle delen av Lærerveiledningen til Konfirmantbibelen $2015^{5}$.

Med sin interesse for og glede av å undervise, har hun blitt filmet til bruk i nettbaserte emner og har også hatt faglig ledelse av innspilling av korte videoer med skuespillere til bruk i lærerutdanning. Interessen hennes for arkitektur og estetikk har kommet til uttrykk i både undervisning og publikasjon.

Som forsker og formidler har hun vært svært produktiv, noe hennes nærmere 150 innførsler i den nettbaserte katalogen Cristin dokumenterer. En relativt fersk og spennende artikkel ble skrevet sammen med en fagpedagog ved ILS og publisert i Prismet. ${ }^{6}$ Det dreier seg om en kvalitativ empirisk longitudinell studie blant ungdom i alderen 15-19 år i Groruddalen. Erfaringer fra både ungdomsskolens (RLE) og videregående skoles (RE) religions- og livssynsfag dekkes. Teoritilfanget i artikkelen spenner fra Bernstein (vertikale og horisontale kunnskapsdiskurser) til Aristoteles (episteme, techne og fronesis), dessuten anvendes Leganger-Krogstads egen analysemodell for kontekstuell religionsdidaktikk i en tolkning av det empiriske kildematerialet. Både denne artikkelen og flere andre publikasjoner viser at Leganger-Krogstad ikke forlot den skolerettede religionsdidaktikken til fordel for kirkelig didaktikk da hun ble tilsatt ved MF. Hun har fortsatt å bidra på begge samfunnsarenaene, og står for en bred tilnærming til religionspedagogikk hvor kolleger med forskjellige målgrupper og kontekster kan lære av hverandre. Hovdenak og Leganger-Krogstads artikkel har en avslut-

4 Se Krupka, B. \& Leganger-Krogstad, H. (2013). Der Umzug des Religionsunterrichts von der Schule in die Kirche. Gelingt die Einrichtung eines kirchlichen Unterrichtsprogramms für den Religionsunterricht ausserhalb der Schule in Norwegen? I: Zeitschrift für Pädagogik und Theologie 65 (1), s. 54-67.

5 For mer fullstendig publikasjonsliste, se: https://www.mf.no/ansatte/3378

6 Hovdenak, S. S. og Leganger-Krogstad, H. (2018). ««RLE er egentlig et av de viktigste fagene». Religion som fag - sett fra elevperspektiv.» I: Prismet 69 (1), 27-50. 
ning hvor forfatterne kommer med kritisk konstruktive innspill til den pågående fagfornyelsen idet de drøfter offentlige dokumenter, fra Ludvigsen-utvalgets NOU i 2015 til første høringsrunde angående kjerneelementer for KRLE-REfaget i oktober 2017. Det advares mot at faget făr en for sterk samfunnsfaglig profil på bekostning av «kunnskap fra og om varige tekstlige kilder, historie og kulturtradisjoner». I sin lange og vidtfavnende religionspedagogiske forskningsinnsats har professor Leganger-Krogstad vist evne til samarbeid mellom fagdisipliner og på tvers av landegrenser, samtidig som hennes egen religionsdidaktiske tilnærming og profil har vært klart uttrykt. 